The Voluntary Food Intake of Pigs

Occasional Publication No. 13-British Society of Animal Production 1989

edited by J. M. Forbes, M. A. Varley and T. L. J. Lawrence

\title{
THE EFFECTS OF SEASON, SEX AND BREED ON PIG FOOD INTAKE AND PERFORMANCE
}

\author{
L. C. HSIA and G. H. LU
}

Pig Research Institute, Taiwan, PO Box 23, Chunan, Miaoli, Taiwan 35099

\section{INTRODUCTION}

$\mathbf{T}$ here is a strong positive relationship between the food intake and the performance of pigs. However, the food intake of pigs can be influenced by many factors. The reduction of food intake of growing and finishing pigs under high environmental temperature is a familiar phenomenon (Heitman, Kelly and Bond, 1958; Hazen and Mangold, 1960; Mangold, Hazen and Hays, 1967; Hsia and Lu, 1987a and b; 1988a and b). Hsia and Lu (1987a and b) reported that the food intake of pigs can differ proportionately by about 0.25 to 0.35 between the warm and cold seasons. Food intake variation between sexes has also been reported (Fuller, 1984). Other reports have also shown that the food intake of pigs of selected lines fell below that of the control line (Brandt, 1987). The present experiment was designed to investigate the extent to which the food intake of different breeds or different sexes varies under different seasons.

\section{MATERIAL AND METHODS}

A total of 192 growing and finishing pigs of four breeds, Duroc (D), Danish Landrace (L), Yorkshire (Y) and three-way-crossed pigs (LYD) were used in this experiment. The test was conducted once in summer and once in winter with an equal number of pigs (half castrated boars and half gilts) of each breed. Six pigs were kept in each pen. The average initial body weight was $20.1 \mathrm{~kg}$ and the average final body weight was $95.9 \mathrm{~kg}$. The crude protein content of the food was $160 \mathrm{~g} / \mathrm{kg}$ and the digestible energy content was $14 \cdot 15 \mathrm{MJ} /$ $\mathrm{kg}$. Food was provided ad libitum and replenished once daily and the residue of food was collected and weighed the next morning. Pigs were weighed once weekly and water was provided ad libitum.

\section{RESULTS AND DISCUSSION}

There were significant differences in food intake among breeds $(P<0.01$; Table 1$)$; that is, the LYD pigs had higher food intakes than the other three breeds and the $L$ had the lowest food intakes. The LYD pigs had the highest weight gains and the $\mathrm{L}$ had the lowest weight gains among the four breeds. There was no significant difference in food conversion efficiency among the four breeds $(P>0.05)$.

The pigs ate significantly more food in the cold season than in the warm season $(P<0.01)$. Weight gain of pigs was also significantly higher in the cold season than in the warm season $(P<0.05)$. However, the food conversion efficiency was significantly better in the warm season than in the cold season $(P<0.01 ;$ Table 1$)$.

The castrated boars had significantly higher food intakes and weight gains than the gilts $(P<0.05)$. There was no significant difference in food conversion efficiency, between the two sexes (Table 1). There was no

TABLE 1

The effect of season, sex and breed on pig food intake and performance

\begin{tabular}{|c|c|c|c|c|c|c|c|c|}
\hline \multicolumn{5}{|c|}{ Breed } & \multicolumn{2}{|c|}{ Sex } & \multicolumn{2}{|c|}{ Season } \\
\hline $\begin{array}{l}\text { Duroc } \\
\text { (D) }\end{array}$ & $\begin{array}{l}\text { Landrace } \\
\text { (L) }\end{array}$ & $\begin{array}{c}\text { Yorkshire } \\
\text { (Y) }\end{array}$ & LYD & Significance & $\begin{array}{l}\text { Castrated } \\
\text { male }\end{array}$ & Female & Cold & Warm \\
\hline 0.635 & 0.549 & $0 \cdot 612$ & 0.666 & $* * *$ & $0 \cdot 648$ & $0.583^{* * *}$ & 0.633 & $0.598^{* * *}$ \\
\hline 2.004 & 1.893 & 1.995 & $2 \cdot 155$ & * & $2 \cdot 145$ & $1 \cdot 879^{* * *}$ & $2 \cdot 141$ & $1 \cdot 882^{* * *}$ \\
\hline $3 \cdot 194$ & $3 \cdot 404$ & $3 \cdot 284$ & $3 \cdot 220$ & & $3 \cdot 294$ & $3 \cdot 258$ & 3.398 & $3 \cdot 153^{* * *}$ \\
\hline
\end{tabular}


significant interaction among breeds, seasons or sex treatments.

Those results suggest that all breeds used in the present experiment showed similar responses to the high environmental temperature. It seems that no breed is especially resistant to high environmental temperature.

\section{REFERENCES}

BrandT, H. 1987. Development and genetic aspects of feed intake in three breeds of pigs at German test stations and measures to prevent further deterioration. Pig News and Information 8: 29-33.

Fuller, M. F. 1984. Sex difference in the nutrition and growth of pigs. In Recent Developments in Pig Nutrition (ed. D. J. A. Cole and W. Haresign), pp. 177-189. Butterworths, London.

HAzen, T. E. and MANGOLd, D. W. 1960. Functional and basic requirement of swine housing. Transactions of the American Society of Agricultural Engineers 41: 585.

Heitman, H., Kelly, C. F. and Bond, T. E. 1958. Ambient air temperature and weight gain in swine. Journal of Animal Science 17: 62-67.
Hsia, L. C. and Lu, G. H. 1987a. Performance of three way crossed pigs under hot and moderate cold environment. World Review of Animal Production 23: 9-13.

Hsia, L. C. and Lu, G. H. 1987b. The effect of high environmental temperature on the protein and energy requirement of growing-finishing pigs. 1 . The effect of dietary levels of protein and energy on the performance of pigs under ad lib feeding. Journal of the Chinese Society of Animal Science 16: (1-2), 1-10.

Hsia, L. C. and Lu, G. H. 1988a. The effect of environmental temperature and energy level on food intake of finishing pigs. Proceedings of the VIth World Conference on Animal Production, 1988. In press.

Hsia, L. C. and Lu, G. H. 1988b. Nutrient requirement of growing finishing pigs when fed ad libitum under hot and cool seasons. 1. The effect of energy level of food on the performance of finishing pigs. Journal of the Agriculture Association of China 141: 62-66.

Mangold, D. W., Hazen, T. E. and Hays, V. W. 1967. Effect of air temperature on performance of growing and finishing swine. Transactions of the American Society of Agricultural Engineers 10: 370. 